\title{
Competitiveness of SMEs: The support of value creation and market orientation
}

\author{
Pande Putu Buda Prasada ${ }^{a^{*}}$, Erie Febrian ${ }^{a}$, Rita Komaladewi ${ }^{\text {a }}$ and Wa Ode Zusnita ${ }^{a}$
}

${ }^{a}$ Universitas Padjadjaran, Bandung, Indonesia

\begin{tabular}{l}
\hline C H R O N I C L E \\
\hline Article history: \\
Received: July 7, 2020 \\
Received in revised format: \\
August 102020 \\
Accepted: August 17, 2020 \\
Available online: \\
September 2, 2020 \\
\hline Keywords: \\
Entrepreneurship \\
Competitiveness \\
Value Creation \\
Distinctive Competencies \\
Market Orientation \\
\hline
\end{tabular}

\section{A B S T R A C T}

Firms' competitiveness plays an important role to achieve better performance and entrepreneurship; however, competitiveness needs to be supported by internal resources. The purpose of this paper is to examine the support of value creation, distinctive competencies, and market orientation on competitiveness creation by an entrepreneur. The study is based on the competitiveness phenomenon of SMEs in Jakarta, associated with the performance. So, this experimental research is conducted by a survey among 120 entrepreneur SMEs in Jakarta. The data are collected by questionnaire and data analysis is performed through some statistical tools. For research model, the study examined the result through the research hypothesis test. The result found that value creation correlates with competitiveness creation, market orientation and distinctive competencies which yields competitiveness.

Market Orientation

(C) 2021 by the authors; licensee Growing Science, Canada

\section{Introduction}

Nowadays, most companies determine a business strategy created by empowering internal resources for achieving optimum performance (Palacios-marqués et al., 2011). Companies also try to create a competitive business strategy (Hull \& Rothenberg, 2008). This explains the importance of a company's competitiveness to achieve business performance in competition, and it is undoubtedly applied for both large small companies integrated into SMEs. SMEs are business unit run by a businessman. Small and medium Enterprises (SMEs) have been forward and evenly distributed (Haroon Hafeez et al., 2012). It is different from developing countries to adapt such business strategy (Tambunan, 2005). SMEs' performance surely helps to sustain the economy, particularly in business competition impacted by an unbalancing economy and SMEs are stronger in resisting those cases compared to large companies (Muda \& Rahman, 2016). Successful business strategies are caused by the uniqueness of SMEs in implementing innovation (Haroon Hafeez et al., 2012). Both large and small companies, in creating a company's competitiveness require pillars of business strategy (Saeed et al., 2016). Those cases become fundamental in budgeting resilience, economic stability improvement, and supporting competitiveness enhancement (Hariyanto \& Alamsyah, 2019). Strategy development is surely needed so that the implementation of the company's competitiveness creation becomes easier to get. Today, competitiveness becomes a measurement instrument to assess the power map of competitors with the power of the company internal (Rodriguez-Fernandez, 2016; Syarifuddin \& Alamsyah, 2017). Through this competitiveness, the company can imitate and even overtake the right strategy for the company. Competitiveness can be assessed not only from the product but also through organization or industry (Ritchie \& Brindley, 2009). Competitiveness always is truly assessed by the output produced (Melewar et al., 2012); which means that it needs experience in implementing a business strategy to measure the level of competitiveness achievement so that company often does testing to business strategy through a series of analysis or market research with a conventional product. When we already have a favorable market position to competitiveness, company repairs quickly to its product or service, and even it produces the newest to achieve advantage and its business (Herciu

* Corresponding author.

E-mail address: prasadapande@gmail.com (P. P. B. Prasada) 
\& Ogrean, 2015). However, this business is not always running well, where business strategy runs in the beginning, and it is not accepted well by the market. So that company, through its strategic management, evaluates business strategy implementation by seeing competitors' position. This phenomenon explains that it is not easy to achieve a company's competitiveness for the optimum company's performance because many cases need to consider in sustaining competitiveness. One common thing that is conducted by the company to assess competitiveness is value creation generally (Harrison et al., 2010).

Value creation is the creation of value that will be received by customers when they choose product or service accepted, and the company creates value creation in order the value of product or service receives customer's intention (Alamsyah, Aryanto, et al., 2020). Value creation has positive implications for customers, that strategy impacts to customer's loyalty, and believed to be able to expand company market share (Shamah, 2012). Value creation, as part of the company's strategy, created to encourage the creation of a company's competitiveness recently (Alamsyah \& Febriani, 2020; Husted \& Allen, 2007). A capable business strategy is always related to the value of product or service possessed (Kirlin, 1996). Small companies, as it is on SMEs, are closely related to value creation because SMEs are free in implementing innovation to their product and services compared to large companies (Iturrioz et al., 2015). So it is often stated in previous research that the implementation of value creation is easier on SMEs, and it provides the benefit for company reputation (Haroon Hafeez et al., 2012). Today, Indonesia has many SMEs but there are a few moves to large industries (Tambunan, 2005). Therefore, the government's efforts keep rolling on with several advantages policy for SMEs. Hence, SMEs need to improve themselves and take these chances with some business strategy; in this case, the most possible is value creation to a company's competitiveness creation (Bolívar-Ramos et al., 2012). Business is not long-lasting if the company does not depend on some owned capabilities; furthermore, the distinctive competencies needed to be parallel with the company's goal in business competition.

The distinctive competencies are the company's ability to empower resources owned by a series of strategies on product or service, which is hard to be imitated by the competitors (Alamsyah, Othman, et al., 2020; Leoni \& Gritti, 2016). At first, the company generally becomes the primary source of strength because it is tremendously impacted by competitive advantage (Cappelli \& Crocker-Hefter, 1996). Nowadays, the distinctive competencies can be applied to SMEs since the product and service of SMEs are possible to innovate quickly through distinctive competencies. The company has genuinely some resources which are called by an asset, but a few who comprehend to empower a qualified asset (Palacios-marqués et al., 2011). The distinctive competencies come from empowering superior company assets as a source planning business strategy. It is well illustrated in tangible or intangible of company assets so that the use of the asset is more precisely associated with the company's performance (Bryson et al., 2007). It explains the importance of prioritizing the unique capabilities of superior companies to get a competitive advantage and to create a company's competitiveness (Hikmawati \& Alamsyah, 2018; MartínRojas et al., 2013). So that, SMEs in Indonesia can have an advantage in competition with the creation of competitiveness if they can gather core capability and to implement it effectively and efficiently. In addition to the unique capabilities, some strategies are related to the company's competitiveness, particularly in SMEs, which is market orientation (Maryam et al., 2014). In previous research, there was a significant relationship between competitiveness achievement and the empowering of market orientation (Lopes-Costa \& Munoz-Canavate, 2015) since market orientation is directly related to the target market of customer's behavior. Market orientation reveals a long-term relationship between a company and its customers, so it is often associated with long term benefits. In small companies which included in SMEs, market orientation is often a measure of success, because SMEs rely heavily on customers' intention (Lopes-Costa \& Munoz-Canavate, 2015). Nowadays, market orientation is also used as a weapon in the business competition through value creation, and it impacts directly on business performance (Mahmood, 2013; Setiadi et al., 2018). Analysis of market orientation phenomenon seems to be critical in assessing market orientation, particularly to create the company's competitiveness in SMEs, which have a closer correlation to market orientation. Furthermore, based on the phenomenon of competitiveness at SMEs in Indonesia with various business strategies, the research focus is on studying the achievement of SME's competitiveness. The research was conducted by managing other factors that have an impact on competitiveness, which is the creation of value created, the unique capabilities that are possessed, and the implementation of market orientation of SMEs in Indonesia. So, it can see what factors can create a company's competitiveness, through a study of value creation, the unique capabilities, and market orientation.

\section{Literature Review}

\subsection{Value Creation}

In holistic marketing, value creation is closely related to business performance (Shamah, 2012) in which customers need the value of product chosen and used so that the value obtained is in line with their expectations (Shabbir et al., 2015). It explains that value creation in business strategies is the basis of marketing strategies, capturing customers' needs for the value of products or services. The creation of actual value in the process collaborates with several essential elements of the company, which are management, customers, and intermediaries or suppliers (Husted \& Allen, 2007). All are collaborating to explore the value which is needed by customers; if it is possible to create the value which is beyond customers' expectations so that companies have a competitive effect on the value creation received by customers. The company will be able to create value creation when the company has focused on the target market; in this case, it is a core of customers (Biggemann et al., 2014). It continued by recognizing the core competencies which are possessed and manage them into resources that have value, and can be accepted by customers (Agrawal \& Rahman, 2015). The most important issue in this process is the involvement of 
third parties, such as suppliers, so that business networking makes it easier to recognize the target market (Kirlin, 1996). In theory, the value creation is something offered by business entities and getting transformation through customer's involvement jointly with business entities to create the value (Prahalad \& Hamel, 1990). The theory explains a clear relationship between the value creation and target market for customers. Value creation is related to the increase in value, which can have an impact on the increase of customers' loyalty (Shabbir et al., 2015). It means that it needs to receive attention for customers when it is related to the value creation and its impact on customers' loyalty. In previous research, associated with the concept of value creation business reveals that the process of value creation must understand from three value perspectives (O'Cass \& Ngo, 2011), which includes creating value for customers, a value in an offer, and value in use. It means that customers will receive several values; which depends on the company's perspective related to the value that will deliver to customers. Value creation for companies has been considered as the core of company competition since each company has determined business strategies that lead to the value expected by customers (Husted \& Allen, 2007). By knowing the complexity of values, a business strategy created can deliver to companies to find competitiveness in competition (Biggemann et al., 2014). In this study, the value creation has a focus on customers' studies, so the measurement focuses of value creation is seen from the perspective of customers, wherein previous research can learn through several things, which is its core competence in the business domain, and its collaborative network on business partners (Kotler \& Keller, 2012). Furthermore, this synthesis means that a business entity can create customer value if it can always focus on customers, having qualified of the core competencies that are related to customer's benefits, business domains and business partners (Tsai et al., 2012). In this case, value creation used as a business strategy of the company with a study of the impact on a company's competitiveness (Du et al., 2007), and it has also known a significant correlation between value creation and the creation of the company's competitiveness (Husted \& Allen, 2007).

\subsection{Distinctive Competencies}

Distinctive capabilities are related to a company's internal resources, which are managed into a superior business strategy (Mooney, 2007). The distinctive capabilities are not easy to obtain, except in companies that have experience in business competition (Lee \& Rao, 2009). The importance of assessing the distinctive capabilities is because companies often misjudge their capabilities, making business strategies that quickly imitated, and it tends not to be well received by their customers (Palacios-marqués et al., 2011). The capabilities of the company need to collaborate (Bryson et al., 2007) because all elements of the company have their interests from the company's capabilities. Capability refers to the ability, which is informationbased, tangible, or intangible processes that are expressly owned by the company, and developed over time through complex interactions between other company resources (Martín-Rojas et al., 2013). It means that there is a complexity in creating the unique capabilities of the company to support the company's performance. Sometimes company's capabilities are considered imperfect, and it needs to be more productive in its implementation, as well as the flexibility of strategies to protect the products and services produced by the company (Mooney, 2007). The previous studies explain that the distinctive capabilities correlate with the creation of a company's competitiveness (Palacios-marqués et al., 2011) since capability is a strategy in achieving a company's competitive advantage. In determining the company's capability, a strategy needed to be able to create value for customers, and it can create capabilities that are not easily imitated by competitors (Bolívar-Ramos et al., 2012). The general study of the unique capabilities relates to a collection of competencies that crosses divisional boundaries, spreading out in the company, and it becomes something that can be done much better by the company (Wheelen \& Hunger, 2012). The unique capabilities are associated with capabilities advantages possessed by a company that has been managed well into a business strategy that is not easily imitated by competitors (Cappelli \& Crocker-Hefter, 1996). The unique capacity as a valuable asset of the company needs to be maintained because it can become a sustainable competitive advantage (Mooney, 2007). The term capability emphasizes the critical role of strategic management in adapting, integrating, and reconfiguring organizational skills, resources, and functional competencies to match the demands of a changing environment (BolívarRamos et al., 2012). In high-speed markets, the ability to renew competencies to accommodate changes in the business environment is essential, and it called dynamic capabilities. The concept of the unique capabilities is the process of identifying the strengths and the characteristics of business entities and their exploitation in creating a particular product by them and they will realize the competition in the market (Palacios-marqués et al., 2011). Its application means that managers must find and understand the capabilities of their business entities in competition and how far they can fulfill the necessities and requirements for customers (Bryson et al., 2007). Indeed, the unique capabilities can be assessed base on several criteria in business strategies, including tangible and intangible assets (Wheelen \& Hunger, 2012), but in a study, it revealed that the capability of organization also has an essential role in assessing the unique capabilities (Palacios-marqués et al., 2011), and it is necessary to evaluate its performance in SMEs which have different characteristics with large companies.

\subsection{Market Orientation}

In market competition, market orientation is one of the best strategies for the company because it is directly related to customers (Maryam et al., 2014). Moreover, it is well known that market orientation is closely related to the extent of market share possessed, and market share closely related to the achievement of the company's performance (Roberts, 1990). Companies are very familiar with market orientation; it always associates their business strategy with customer behavior (GallardoVázquez \& Isabel Sánchez-Hernández, 2014). It implies the importance of market orientation in business competition and the company's performance, but it needs to realize the market orientation is sourced from the company so that the involvement of 
stakeholders is expected (Zhou et al., 2005). Furthermore, when a company has a directed strategy to market orientation, the achievement of the company's performance will be easier to do, and the most important thing is the business sustainability of the company (Maryam et al., 2014). Today, there are a lot of economic changes around the world and it has an impact on company management, which requires managers to change business strategies that are resistant to economic shocks (GallardoVázquez \& Isabel Sánchez-Hernández, 2014). The economic change also surely has an impact on the difficulty of company management in changing the decisions which have made for products and services, particularly in large companies, unlike the small-scale companies that exist in SMEs, where it is easier to resist economic shocks. One reason is that the absorption of innovation at SMEs is easier when economic changes occur (Risal et al., 2016). Innovation in companies is closely related to the value of products or services that will be received by customers, and now customers are susceptible to the value that will be received (Maryam et al., 2014). The phenomenon of value for customers positively affects the company's business strategy, which prioritizes customers' value, and if necessary and it exceeds customers' expectations. To compete in an aggressive and interactive company, a company must shift its business focus from trading transactions to maximizing customer value, intended for more prolonged company survival. This competition has entered to market orientation area, and every company has realized those cases to become part of a business strategy (Nasution et al., 2011).

Market orientation is a stage where a company makes customer's condition through the value of products and services (Maryam et al., 2014). The theory explains the importance of market orientation by prioritizing customers' intention, which is in line with the company's intention. Companies that have a market orientation continually strive to provide the bargaining power of products and services following market intention continually and a long time (Gabler et al., 2015). To understand market orientation, companies need to collaborate all of the elements in marketing to be in line with their market potential (Messersmith \& Wales, 2013). Company organizations must monitor the changes of needs and customers' intention quickly, determining the impact of these changes on customer behavior, increasing the rate of product or service innovation, and implementing the strategies which build an organization's competitive advantage. A company that comprehends to market is always looking for information related to customers, market conditions, market competitors and even matters relating to the market as a reference for further business and development (Risal et al., 2016). It is followed up by planning strategy based on customer value and customers' satisfaction. The most important thing from market orientation is the involvement of all elements in the marketing department to anticipate market intention as a reference for integration with internal resources, making it as information of the next marketing strategy (Messersmith \& Wales, 2013). A market-oriented organization is always committed to continuously improving the best service for customers.

Market orientation becomes a sustainable business orientation when it can provide benefits for customers in a long period so that the competitiveness of business strategy becomes the main thing that needs to be considered by marketers (Philip Kotler \& Armstrong, 2006). Market orientation cannot be truly separated from the marketing mix, because customers certainly pay attention to the marketing mix given by the company (McCarthy et al., 1997). The essence of this opinion emphasizes the company's relationship with customers, which is bridged by a marketing mix strategy to create market orientation (LopezRodrigez, 2009). Previous theories have explained that in assessing the market, orientation can do through several things such as market intelligence, intelligence across departments, and organizational responsiveness (Cao et al., 2014). In principle, these measurements explain the importance of supervision of market activities, and it is different from the advanced theories, which explain that market orientation needs to look at several activities like customer focus, intelligent competitors, and crossfunctional cooperation (Cravens \& Nigel, 2009). The theory simplified that, in principle, market orientation depends on customer orientation, competitor orientation, and inter-functional coordination (Narver \& Slater, 1990); at least the three measurements can be the information in making business strategies that have competitiveness. The success of the company in business competition depends on the company's ability to determine business strategy, however determining business strategy needs to be supported by the readiness of marketing human resources in assessing market needs (Ye et al., 2013). Through market orientation, it is expected not only to be able to create a business strategy for the company but also to create the company's competitiveness and business sustainability.

\subsection{Competitiveness}

A company is said to be able to compete in a business competition if it has competitiveness supported by business strategies (Adisu, 2014); business strategies are always associated with competitive prices, products, superior quality, and high level of service to customers (Tunyi \& Ntim, 2016). This theory explains that competitiveness is very influential in achieving excellence in the competition, which puts forward to excellent price, quality, and service. Competitiveness created by companies is certainly not natural, it needs the support of superior company resources as well, or creating superior resources based on company experience (Ptacek et al., 2015). The final result of the company can create superior competitiveness after empowering superior resources (Hitt et al., 2013). It has known before that the company's strategy is closely related to the company's competitiveness, various strategy formulations created to give satisfaction to customers for the value creation, which has been created by the company that has the final impact on the recognition of company's competitiveness (Hidayat \& Akhmad, 2016). Those cases are surely giving opportunities for the company and making them ready for business competition by knowing the source of excellence in the internal company. The previous studies have explained that there is a method that can be used by companies in increasing competitiveness on market competition by using a supply chain (Cao et al., 2014). The company's supply becomes a pending part of the company's life path in business competition because it can involve in the creation of 
company resources owned for the creation of business strategies (Ganesan et al., 2009). Nowadays, even companies often use supply chains as part of implementing the support of business strategy (Shamah, 2012). The phenomenon of the theory above explains the importance of a company's competitiveness in the efforts of supporting the creation of a company's performance so that the implementation of business strategies of the company prioritizes the final goal of achieving competitiveness (Trendafilova et al., 2013). In general, competitiveness is related to business competition (Lynes \& Andrachuk, 2008), but it needs optimum support from various parties in the company to achieve competitiveness that leads to the company's performance (Cao et al., 2014). Finally, in business competition, competitiveness needs to be linked to the resources owned (Porter, 2008); it assesses the importance of managing internal resources in creating a company's competitiveness. Those cases also reveal implicitly that one of the characteristics of competitiveness's condition is how a company implements the speed of response for competitors' and customers' behavior. The company competes to find competitiveness, and one of the goals of determining competitiveness is when a company can provide the best value for products and services offered (Casado \& Pel??ez, 2014). For large-scale companies, competitiveness is a non-negotiable competitive model to be implemented (Dupeyras \& Maccallum, 2013), it is different from small-scale companies where competitiveness sometimes is not the main thing because it is unclear to market competition. The study of competitiveness model is often used as a business competition strategy in large companies, so the research of competitiveness model that has been successful in one company is often used as the company's main adaptation today. Competitiveness can genuinely assess through several measurements of business strategy; however, in assessing a company's competitiveness is demanded to measure accurately. In previous studies, it said that there were their main things in assessing a company's competitiveness, which is at the level of differentiation, competitive price units, and the duration of trade (Ritchie \& Brindley, 2009). The theory emphasizes the importance of assessing competitiveness and differentiation's level that is owned by the company through its resources. However, not all companies have unique resources, so that the creation of competitiveness is not successful. It appears that competitiveness needs to be a concern because the limitation of resources has not become a reason for business strategy limitations. After all, the unique resources can still create by the company's collaboration (Zhou et al., 2005). Also, in the creation of competitiveness, the company does not always judge from the unique resources, but it assesses from the creation of unique product values, and it is not initiated by competitors so that the achievement of competitiveness can be achieved (Mashahadi et al., 2016). Many previous studies explain that external resources generate the importance of competitiveness; one of them is a collaboration (Hegerty, 2016). Since it is not to take the company's advantage, it is not only from the company's internal factors but from the outside of the company is also able to support it, such as cooperation with policymakers, which is government. However, companies still need to be alert when collaborating with external parties because the policy changes are sometimes not in line with the company's intentions, especially when determining the value of products and services offered that depends on the external policy (Henckens et al., 2016). The final goal of creating competitiveness is the achievement of a company's performance and business sustainability, so the right measurements through qualified business strategies need to be considered. The basic theory is related to the competitiveness of the World Economic Forum is explained as a set of institutions, policies, and factors that determine productivity's level of the company in conducting business (Seelos \& Mair, 2005). The theory explains the importance of managing competitiveness by collaborating with all elements that are involved in business competition. It means that the company does not need to focus on the company's internal as well as the company's external if it is possible, to achieve business competitiveness enough. Because in principle, competitiveness can be a series of efforts in the company's ability to enter the market and the ability to survive in that market (Porter, 2008). Furthermore, generally, there are studies related to the measurement in assessing competitiveness, which is focusing on customers, focusing on paying attention to competitors, and the involvement of all functional elements of the company in creating competitiveness (Cravens \& Nigel, 2009).

\section{Research Method}

\subsection{Method and Research Measurements}

The research conducted included 120 entrepreneur SMEs in Indonesia and it became as one of the economic development goals from Indonesian's government. Data and information obtained through questionnaire in Likert scale with the values of " 1 " to " 5 ", and analyzed through Lisrel analysis tools. The research variable in this study focused on value creation, distinctive competencies, market orientation, and competitiveness. The previous researches stated that a company's competitiveness could be influenced by value creation (Husted \& Allen, 2007), distinctive competencies (Cappelli \& Crocker-Hefter, 1996), and market orientation (Chan et al., 2012). Three strategies measured all of the variables except for the competitiveness variable through four measurements.

\subsection{Model and Research Hypothesis Design}

Data source from entrepreneur SMEs were obtained in 2019, and were processed by a research model, which is regression analysis as shown in Fig. 1. Before it is analyzed, those research models conducted model testing and research hypothesis testing, here is research hypothesis design as follows.

$\mathrm{H}_{1}$. Value Creation influences the Competitiveness of SMEs

$\mathrm{H}_{2}$. Distinctive Competencies influences the Competitiveness of SMEs

$\mathrm{H}_{3}$. Market Orientation influences the Competitiveness of SMEs 


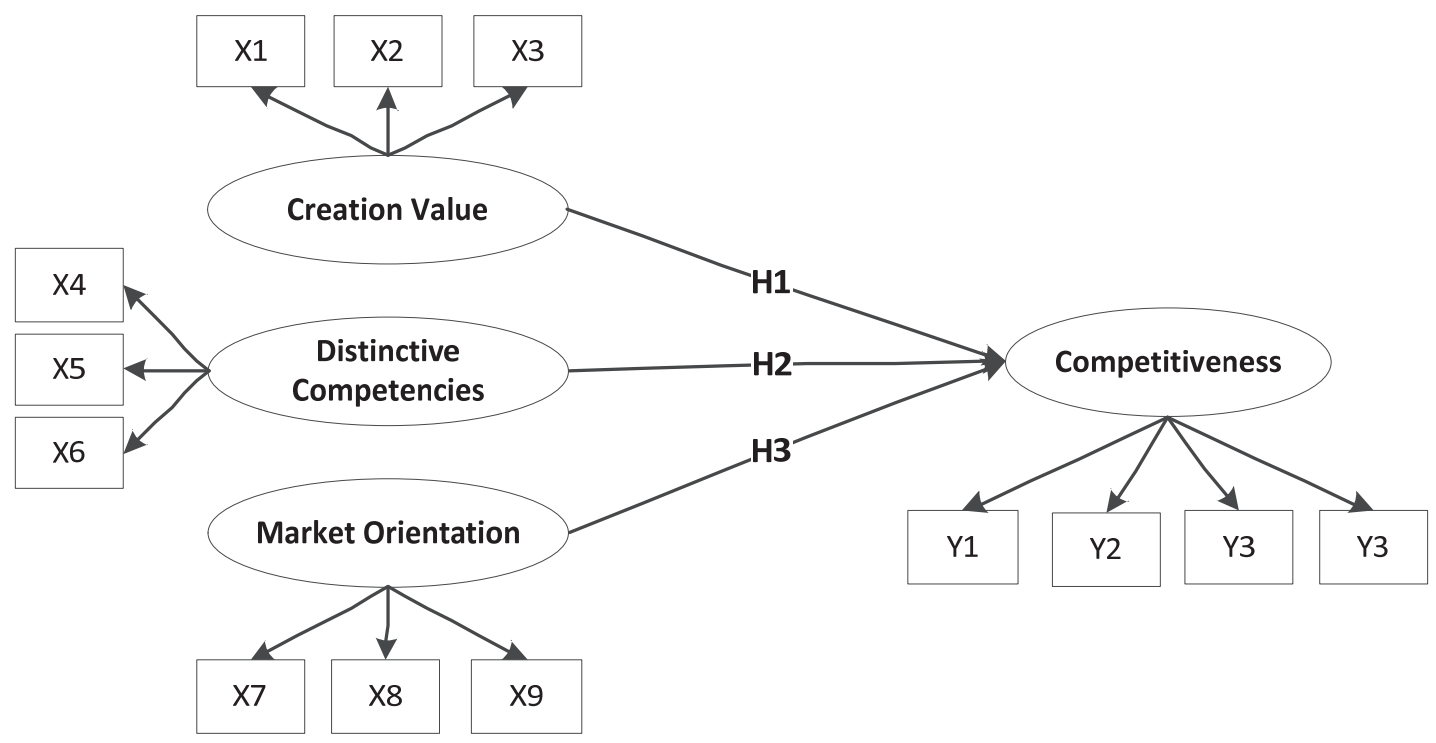

Fig. 1. Research Hypothesis Model

\section{Research Result and Discussion}

Data obtained from 120 entrepreneurs SMEs by distributing questionnaires; all of the data were processed without describing a profile of respondents and a description of the respondent's answer. Data processed through some stages, such as the validity and reliability test of research instruments.

\subsection{The Result of Research Instrument Test}

The first result repots the validity and reliability of the research instruments, where there are variables, research instruments, Pearson correlation values, and Cronbach's alpha. It is known that based on the result of data processing for Pearson Correlation, all values are above 0.6 , and explain that all of the instruments are valid since they are above 0.5 as a basic value. Details of all values are given in Table 1.

Table 1

Validity and Reliability Test of Research Instrument

\begin{tabular}{|c|c|c|c|}
\hline Variables & Instruments & Pearson Correlation & Cronbach's Alpha \\
\hline \multirow[t]{3}{*}{ Value Creation } & Customer Benefit & 0.770 & 0.731 \\
\hline & Business Domain & 0.821 & \\
\hline & Business Network & 0.757 & \\
\hline \multirow[t]{3}{*}{ Distinctive Competencies } & Tangible Asset & 0.700 & 0.674 \\
\hline & Intangible Asset & 0.749 & \\
\hline & Capability Organization & 0.881 & \\
\hline \multirow[t]{3}{*}{ Market Orientation } & Segmenting & 0.840 & 0.714 \\
\hline & Targeting & 0.880 & \\
\hline & Positioning & 0.690 & \\
\hline \multirow[t]{4}{*}{ Competitiveness } & Product & 0.718 & 0.707 \\
\hline & Price & 0.676 & \\
\hline & Place & 0.797 & \\
\hline & Promotion & 0.757 & \\
\hline
\end{tabular}

\subsection{The Result of the Structural Model Test of Research Hypothesis}

The second result has presented a good of fit structural model that is explained the feasibility of the research model. The results in Table 2 have been explained for all measures of conformity, which are Degrees of Freedom, Chi-Square, and PValue, which fulfills the conclusion that the research model is good for a fit. Examining the structural model test results, it can be analyzed research model that has appeared in Fig. 2, as a research result on the regression analysis model. In the research model, it is known that all of the antecedent variables are value creation, distinctive competencies and market orientation correlate competitiveness at SMEs in Jakarta. 
Table 2

Good of Fit Structural Model

\begin{tabular}{|c|c|c|c|}
\hline Size of Suitability & Cut of Value & Value of Research Result & Note \\
\hline Degrees of Freedom & $\leq 1.00$ & 0 & Fit \\
\hline Chi-Square & $\leq 1.00$ & 0.0 & Fit \\
\hline P-Value & $>0.05$ & 1.00 & Fit \\
\hline
\end{tabular}

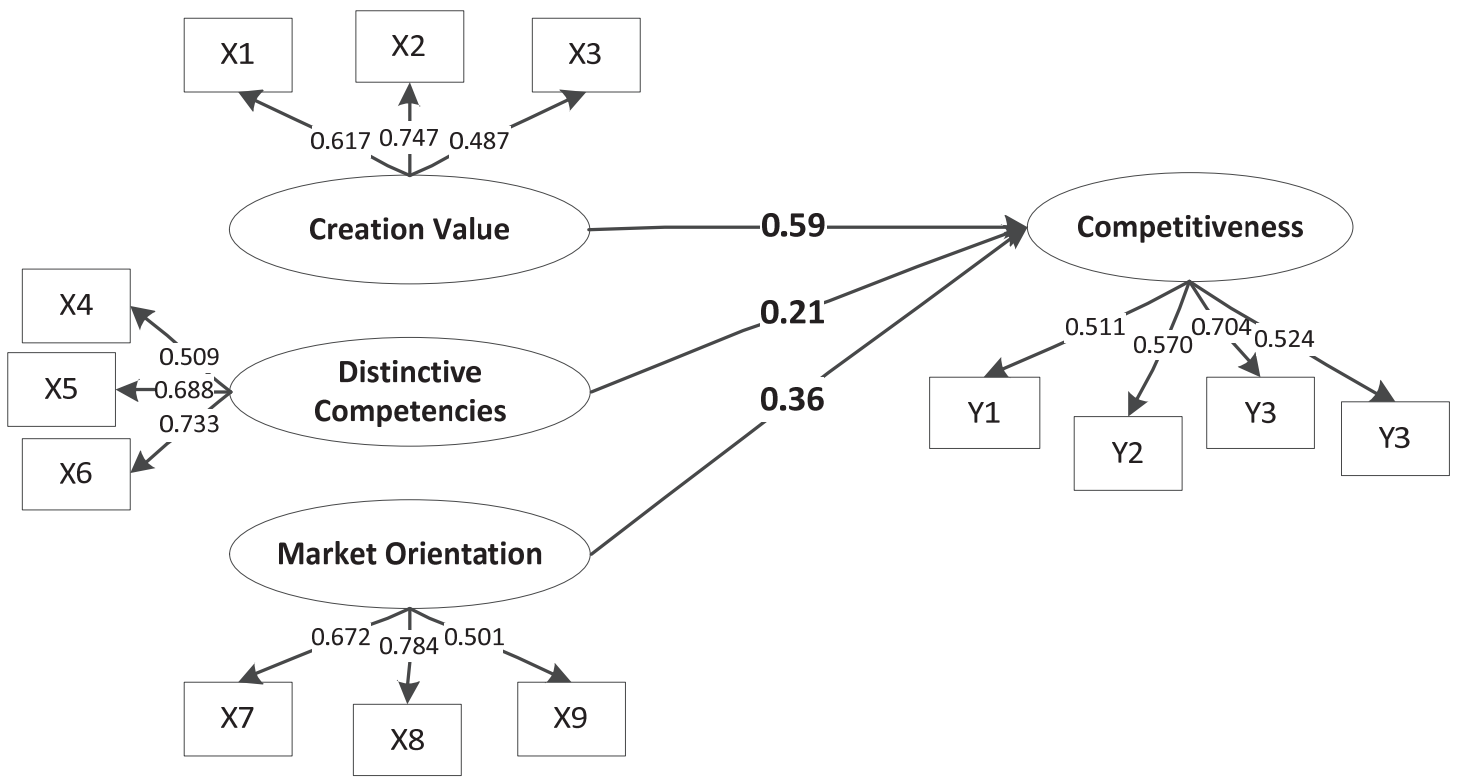

Fig. 2. Result of Research Model

Table 3

Summary of Research Hypothesis Test

\begin{tabular}{|c|c|c|c|}
\hline Hypothesis & Research Hypothesis Test & Result of t-statistics & Result \\
\hline H1 & Value Creation to Competitiveness & 5.19 & Support \\
\hline $\mathrm{H} 2$ & Distinctive Competencies to Competitiveness & 2.02 & Support \\
\hline $\mathrm{H} 3$ & Market Orientation to Competitiveness & 2.70 & Support \\
\hline
\end{tabular}

The final result of this research is the research hypothesis test, where the results of the hypothesis testing have been summarized in Table 4. Hypothesis test results are known to be accepted for all of the hypotheses namely $\mathrm{H}_{1}, \mathrm{H}_{2}$, and $\mathrm{H}_{3}$, considering the value of t-statistical result which is above 1.69. Next, each research result is explained in research findings based on the results of the research hypothesis test.

\subsection{The first hypothesis: The effect of Value Creation on Competitiveness Creation}

Fig. 2 explains that value creation correlates with competitiveness with a positive correlation value $(\beta=0.59)$. A close relationship between value creations in competitiveness explains the better support of value creation; SMEs can create better competitiveness. Not all SMEs in Jakarta have realized the importance of value creation, but inadvertently they used it through an innovative approach to their products or services offered. This organizational behavior is profitable for SMEs and delivers indirectly SMEs to competitiveness. It seems from SME's behavior that it has generally resilience to economic shocks both in Jakarta and in other countries. Part of this research finding is actually in line with studies that have been conducted before (Husted \& Allen, 2007), so these research findings complete the previous studies.

The interesting thing from this research is the support of value creation, where the value creation is created by the company and it has three measurements that focus on business strategies which are customer benefits, business domain, and business networking. From the three strategies in value creation, factor analysis is performed to find out the support of the most impact indicators on value creation; based on Fig. 2, it is known that the rank of priority of the strategies for value creation from business networking is followed by the business domain and it ends with customer benefits. Business networking becomes the first thing to consider in value creation; considering the highest of the loading factor, value is 0.487 . it seems clear that value creation depends on how far the company can manage all of the obstacles that come from the outside of the company as input and strength of the company (Cesinger et al., 2016). Many companies interact with the environment both with the government, competitors, suppliers, and customers as stakeholders (Parola et al., 2013). Therefore, a business network of the 
company can control the environment outside of the company as a support in creating value creation for the company's products or services. A true business networking is a company's market knowledge, collaboration relationship in business networking which has many advantages besides knowing the competitors also adding business opportunities. The essence of the study from business networking confirms the importance of business networking in value creation. The second thing that must be noticed from value creation based on factor loading values is the business domain. The business domain in SMEs is related to the core of product services, as well as the originality of products offered. Each company will provide products or services for customers is adjusted to the core of resources possessed, it is adjusted to the local culture of customers, to products and services are accepted. So that the origin of products or services at SMEs is an important thing for marketers to be considered in connecting with the value creation created. Finally, the determinant factor of value creation is customer benefits, which is offering products or services that are assessed by customers as having the best value for them; customer is the final goal of each marketing strategy of company, so company creates a product or service not only offering it, but it creates a product or service which is more valuable than a similar product from competitors or it is owned by customers. Because the true concern of the product is the value will be received by customers and it must be higher than customer's expectations. The study of three measurements through the strategies listed in value creation is ultimately able to support value creation has a positive impact on a company's competitiveness.

\subsection{The second hypothesis: The effect of the negative value of the distinctive competencies to competitiveness}

The next research finding of this study is the effect of the distinctive competencies on competitiveness. According to Fig. 2 , it is known that the distinctive competencies has a correlation with SMEs' competitiveness $(\beta=0.21)$. This correlation is certainly good for SMEs' competitiveness because it is assessed that the higher of the distinctive competencies of products or services offered by SMEs, the higher of SMEs' competitiveness. Although the correlation of the two is not too close, the positive impact is beneficial for SMEs because the company's capability should be a strength of a superior company than competitors. This finding is in line with the previous studies (Cappelli \& Crocker-Hefter, 1996), and it can be stated that it completes the previous studies, where the distinctive competencies has a benefit for the company's competitiveness. The previous research focused on the theory which is based on the experience of several companies in general. In the same study of SMEs, it was also explained that the distinctive competencies has a good impact on competitiveness (Todericiu \& Stăniţ, 2015), but the study is not conducted in Jakarta so there is a difference with the current study. Examining the differences of opinion on the relationship of the distinctive competencies and competitiveness, this study suggests for the future studies, examining the support of innovation for the correlation between the distinctive competencies and competitiveness, because innovation is one of the uniqueness of SMEs (Crema et al., 2014).

A deeper study of part of the research finding is recommended to examine the support of a distinctive competencies for competitiveness. Since it is considered to be suitable for SMEs in Jakarta; there are still many other factors of business strategy that can be taken to improve SMEs' competitiveness. When it is examined empirically from theory, the previous research explains that competitiveness can be also assessed by the level of innovation (Crema et al., 2014) and the external factors, such as government (Windsor, 2009). Furthermore, it is necessary to know the several things in this research which is the measurement of competitiveness, assessing from the results of the factor analysis which is the best measurement level for distinctive competencies. Based on the sequence, it has the best loading factor value which is capability organization followed by intangible and tangible assets (Fig. 2). All of them are related to assets owned by the company and it controls over these assets, but the most determined is the company's capability in creating competitive assets and it is not easily imitated by competitors. It appears to be a disadvantage of SMEs in Jakarta since it is known from previous researches that SMEs in Jakarta are weak in controlling superior assets (Indris \& Primiana, 2015). The tendency of SMEs to offer products or services which are more easily imitated, so that they are low competitive both nationally and internationally (Tambunan, 2005). It is reasonable if the distinctive competencies in this study is not able to support SMEs' competitiveness. Despite these findings, several factors of distinctive competencies that become SMEs' business strategy which is capability organization, intangible and tangible assets can support the creation of the distinctive competencies, so that they can be used as general information for companies in controlling the unique capabilities.

\subsection{The third hypothesis: The effect of market orientation on competitiveness}

The final finding of this study is the research result of the correlation between market orientation and competitiveness, where based on research finding of Fig. 2 it is clear that market orientation had a positive correlation $(\beta=0.36)$. The essence of the results explains that the better market orientation is created by SMEs, the better improvement on the competitiveness. In market orientation, it is known and assessed by several factors which are segmenting, targeting and positioning. These three factors succeeded in creating a market orientation and it had an impact on SMEs' competitiveness. Also, competitiveness is assessed by several determining factors such as marketing mix strategies, product, price, place, and promotion. All of these factors are business strategies used by SMEs and they can support SMEs' competitiveness. The last part of this research is the correlation of market orientation with competitiveness and it has been examined by previous researches in general (Mashahadi et al., 2016), it explains the implication of the implementation of market orientation on the creation of a company's competitiveness. The essence of these findings is the refinement of previous research results, and it emphasizes the previous results that in controlling the company's competitiveness or SMEs we need support from market orientation. 
The next analysis is a research of the determinant factor of market orientation that needs to be known as company information in determining a company's business strategy. It is known from Fig. 2; targeting is the main determinant factor in determining market orientation. Targeting is related to customers' target of the company because the main target of the company is the customer. In targeting, the company determines the right target market; it starts from the region to the customer's characteristics (Palacios-marqués et al., 2011). A company that focuses on the customer is a company that knows where it is and how the customer utilizes the purchased products (Chan et al., 2012). Customer's character often becomes useful information for the company in determining the next marketing strategy, so that the target market is clearer and makes it easier for the company to find market orientation. Targeting utilizes the main target of customers on more specific products, now the company predicts customers' intention which is adjusted to products or services (Hull \& Rothenberg, 2008). Besides targeting, the determinant factor of market orientation is segmenting, where it talks about the customer is as the main target. This is closely related to customer characteristics, so much information is collected to find out the target of the market segment. Segmentation becomes the beginning of the company to determine market orientation. In some previous researches, it is sometimes equated between market orientation with segmentation, because both of them are focused on customer (Palacios-marqués et al., 2011). But the difference in segmentation is only related to customer's information. So, it is very common if one of the determinant factors of market orientation is segmentation. Surely, if a company focuses on a clear market segment, it can deliver to the good reputation of the company. The changes in customer behavior are closely related to market segmentation (Abdullah \& Sukandi, 2011), so it is very profitable if the company focuses on market segmentation. It is closely related to the company's competitiveness from the perspective of the target market. The final factor of market orientation is positioning, where it talks about the target of the company's intention to be assessed by their customers. This factor is difficult to be created by the company because it needs time and consistency of company, but it can be easily damaged if it is wrong in implementing business strategy. The essence of all market orientation factors explains that it is important to pay attention to the company because it impacts the creation of market orientation and the support of changes in the company's competitiveness.

The study of each research finding according to the research objectives has been presented; most of them can complete the previous researches of the company in general and particularly for SMEs in Indonesia. However, based on some of the results and research findings, the originality of this research is the antecedent of competitiveness. From the three determinant factors for the creation of a company's competitiveness, only two factors can have a positive impact on competitiveness, which are value creation and market orientation. So that the originality of this research is the creation of SMEs' competitiveness in Jakarta through the support of value creation and market orientation. This finding is useful for the company in general or for SMEs in Jakarta which needs to know and manage well the value creation and market orientation because it can create a company's competitiveness. Indeed, many factors can control company's competitiveness, which is controlling business strategy from inside and outside of company (Chan et al., 2012; Palacios-marqués et al., 2011), this time focuses on the internal company and in the future, it should be noticed from outside of company factors that can also control company's competitiveness. Another aspect of competitiveness is the synergy of all internal elements of the company, and collaboration with external elements (Abdullah \& Sukandi, 2011). Because without the support of synergy, competitiveness is not only a business strategy that is easily imitated by competitors. Also, for SMEs in Jakarta to competitiveness is the aggressiveness of the company in finding and controlling unique resources through various innovations and making it a capable business strategy (Hull \& Rothenberg, 2008).

\section{Conclusion \& Suggestion}

Competitiveness is the company's finding on business strategy that is not easy to be imitated by its competitors; it can provide business profit through the company's performance and by entrepreneurs. There are many determinant factors from competitiveness creation such as value creation, distinctive competencies, and market orientation. However, the ablest to determine the competitiveness of SMEs in Jakarta is value creation. A research study of competitiveness has been influenced by value creation, distinctive competencies, and market orientation that truly completes the previous researches, and tends to complete those studies through a current study focuses on entrepreneurs SMEs.

Nevertheless, it is realized that in determining competitiveness, we still need support from other factors, either internal or external, of the company. SMEs in Jakarta is undoubtedly the same with SMEs in the world generally because it has uniqueness in implementing the innovation of both product and service. The company scale becomes the determinant factor, and it becomes a company to be active in facing economic stability in its country. Competitiveness is one of the business strategies that also needs to be noticed by SMEs because the study theoretically can encourage not only performance, but it is closely related to the level of a company's innovation.

Each company has limitations because there is time, and other cases appear when the study conducted; it is the same as the current study. It is suggested for further research to review other factors that have a relationship to a company's competitiveness, which is the innovation level or the support of the government's regulation.

\section{References}

Abdullah, Y., \& Sukandi, P. (2011). The influence of market strategy and value creation on marketing performance. 
International Seminar on Business and Management, 105-111.

Adisu, K. (2014). Chinese economic development and leadership strategy: The challenges of creating competitive advantage. Journal of Economics and Behavioral Studies, 6(2), 163-168.

Agrawal, A. K., \& Rahman, Z. (2015). Roles and resource contributions of customers in value co-creation. In International Strategic Management Review (Vol. 3, Issues 1-2). Holy Spirit University of Kaslik.

Alamsyah, D. P., Aryanto, R., Utama, I. D., Marita, L. S., \& Othman, N. A. (2020). The antecedent model of green awareness customer. Management Science Letters, 10(11), 2431-2436.

Alamsyah, D. P., \& Febriani, R. (2020). Green customer behaviour : Impact of green brand awareness to green trust. Journal of Physics: Conference Series, 1477, 072022.

Alamsyah, D. P., Othman, N. A., \& Mohammed, H. A. A. (2020). The awareness of environmentally friendly products: The impact of green advertising and green brand image. Management Science Letters, 10, 1961-1968.

Biggemann, S., Williams, M., \& Kro, G. (2014). Building in sustainability, Social Responsibility and Value Co-Creation. Journal of Business \& Industrial Marketing, 29(4), 304-312.

Bolívar-Ramos, M. T., García-Morales, V. J., \& García-Sánchez, E. (2012). Technological distinctive competencies and organizational learning: Effects on organizational innovation to improve firm performance. Journal of Engineering and Technology Management, 29(3), 331-337.

Bryson, J. M., Ackermann, F., \& Eden, C. (2007). Putting the resource-based view of strategy and distinctive competencies to work in public organizations. Public Administration Review, 67(4), 702-717.

Cao, Q., Baker, J., \& Schniederjans, D. (2014). Bullwhip effect reduction and improved business performance through guanxi : An empirical study. Intern. Journal of Production Economics, 158, 217-230.

Cappelli, P., \& Crocker-Hefter, A. (1996). Distinctive human resources are firms' core competencies. Organizational Dynamics, 24, 7-22.

Casado, A. M., \& Pelaez, J. I. (2014). Intangible management monitors and tools: Reviews. Expert Systems with Applications, 41(4 PART 1), 1509-1529.

Cesinger, B., Hughes, M., Mensching, H., Bouncken, R., Fredrich, V., \& Kraus, S. (2016). A socioemotional wealth perspective on how collaboration intensity, trust, and international market knowledge affect family firms' multinationality. Journal of World Business, 51(4), 586-599.

Chan, H. K., He, H., \& Wang, W. Y. C. (2012). Green marketing and its impact on supply chain management in industrial markets. Industrial Marketing Management, 41(4), 557-562.

Cravens, D. W., \& Nigel, P. F. (2009). Strategic Marketing. 9th Edition. McGraw-Hill.

Crema, M., Verbano, C., \& Venturini, K. (2014). Linking strategy with open innovation and performance in SMEs. Measuring Business Performance, 18(2), 14-27.

Du, S., Bhattacharya, C. B., \& Sen, S. (2007). Reaping relational rewards from corporate social responsibility: The role of competitive positioning. International Journal of Research in Marketing, 24(3), 224-241.

Dupeyras, A., \& Maccallum, N. (2013). Indicators for measuring competitiveness in Tourism. OECD Tourism Papers, 2013/02, 1-62.

Gabler, C. B., Richey, R. G., \& Rapp, A. (2015). Developing an eco-capability through environmental orientation and organizational innovativeness. Industrial Marketing Management, 45(1), 151-161.

Gallardo-Vázquez, D., \& Isabel Sánchez-Hernández, M. (2014). Structural analysis of the strategic orientation to environmental protection in SMEs. BRQ Business Research Quarterly, 17(2), 115-128.

Ganesan, S., George, M., Jap, S., Palmatier, R. W., \& Weitz, B. (2009). Supply Chain Management and Retailer Performance: Emerging Trends, Issues, and Implications for Research and Practice. Journal of Retailing, 85(1), 84-94.

Hariyanto, O. I. B., \& Alamsyah, D. P. (2019). The Relationship Of Environmental Knowledge And Green Purchase Intention. International Journal of Engineering and Advanced Technology, 8(5), 142-144.

Haroon Hafeez, M., Noor Mohd Shariff, M., \& bin Mad Lazim, H. (2012). Relationship between Entrepreneurial Orientation, Firm Resources, SME Branding and Firm's Performance: Is Innovation the Missing Link? American Journal of Industrial and Business Management, 02(04), 153-159.

Harrison, J. S., Bosse, D. A., \& Phillips, R. A. (2010). Managing for Stakeholder, stakeholder utility functions, and competitive advantage. Strategic Management Journal, 31, 58-74.

Hegerty, S. W. (2016). Commodity-price volatility and macroeconomic spillovers: Evidence from nine emerging markets. North American Journal of Economics and Finance, 35, 23-37.

Henckens, M. L. C. M., van Ierland, E. C., Driessen, P. P. J., \& Worrell, E. (2016). Mineral resources: Geological scarcity, market price trends, and future generations. Resources Policy, 49, 102-111.

Herciu, M., \& Ogrean, C. (2015). Economic Prospects in the Context of Growing Global and Regional Interdependencies, IECS 2015 Wealth, Competitiveness, and Intellectual Capital - Sources for Economic Development. Procedia Economics and Finance, 27(15), 556-566.

Hidayat, R., \& Akhmad, S. (2016). An Integrated Model of Customers ' Satisfaction and Loyality: A Business Analysis of Banking Service. MIMBAR, 32(1), 139-147.

Hikmawati, N. K., \& Alamsyah, D. P. (2018). The digital company based on competitive strategy. Proceedings of the 3rd International Conference on Informatics and Computing, ICIC 2018, 2001.

Hitt, M. A., Ireland, R. D., \& Hoskisson, R. E. (2013). Strategic Management: Competitiveness \& Globalization: Concepts amd Cases, 10th edition. South-Westen. 
Hull, C., \& Rothenberg, S. (2008). Firm performance: The interactions of corporate social performance with innovation and industry differentiation. Strategic Management Journal, 29, 781-789.

Husted, B. W., \& Allen, D. B. (2007). Strategic Corporate Social Responsibility and Value Creation among Large Firms. Lessons from the Spanish Experience. Long Range Planning, 40(6), 594-610.

Indris, S., \& Primiana, I. (2015). Internal And External Environment Analysis On The Performance Of Small And Medium Industries Smes In Indonesia. International Journal of Scientific \& Technology Research, 4(4), 188-196.

Iturrioz, C., Aragón, C., \& Narvaiza, L. (2015). How to foster shared innovation within SMEs' networks: Social capital and the role of intermediaries. European Management Journal, 33(2), 104-115.

Kirlin, J. J. (1996). What Government Must do Well: Creating Value for Society. Journal of Public Administration Research and Theory, 6(1), 161-185.

Kotler, P., \& Keller, K. L. (2012). Marketing Management. Prentice Hall.

Kotler, Philip, \& Armstrong. (2006). Principle of Marketing 11th edition. Person education Ltd.

Lee, J., \& Rao, H. R. (2009). Task complexity and different decision criteria for online service acceptance: A comparison of two e-government compliance service domains. Decision Support Systems, 47(4), 424-435.

Leoni, R., \& Gritti, P. (2016). Institutional Wage Setting, Distinctive Competencies and Wage Premia Empirical Evidence on Italian Employees. Italian Economic Journal.

Lopes-Costa, J. A., \& Munoz-Canavate, A. (2015). Relational capital and organizational performance in the Portuguese Hotel Sector (NUTS II Lisbon). Procedia Economics and Finance, 26(15), 64-71.

Lopez-Rodrigez, S. (2009). Environmental engagement, organizational capability and firm performance. Corporate Governance, 9(4), 400-408.

Lynes, J. K., \& Andrachuk, M. (2008). Motivations for corporate social and environmental responsibility: A case study of Scandinavian Airlines. Journal of International Management, 14(4), 377-390.

Mahmood, R. (2013). Entrepreneurial Orientation and Business Performance of Women-Owned Small and Medium Enterprises in Malaysia: Competitive Advantage as a Mediator. International Journal of Business and Social Science, 4(1), 82-91.

Martín-Rojas, R., García-Morales, V. J., \& Bolívar-Ramos, M. T. (2013). Influence of technological support, skills and competencies, and learning on corporate entrepreneurship in European technology firms. Technovation, 33(12), 417-430.

Maryam, S., Marzieh, T., \& Marzieh, G. (2014). Relationship Among Market Orientation, Service Quality and Organizational Performance From Perspective of Gonbad Kavoos Telecommunication Firm Employees. Advances in Applied Science Research, 5(3), 464-466.

Mashahadi, F., Ahmad, N. H., \& Mohamad, O. (2016). Market orientation and innovation ambidexterity: A synthesized model for internationally operated herbal-based small and medium enterprises ( HbSMEs ). Procedia Economics and Finance, 37(16), 145-151.

McCarthy, D., Puffer, S., \& Naumov, A. (1997). Partnering with Russia's new entrepreneurs: Software tsarina olga kirova. European Management Journal, 15(6), 648-657.

Melewar, T. C., Gupta, S., \& Czinkota, M. (2012). Global business management for sustainability and competitiveness: The role of corporate branding, corporate identity and corporate reputation. Journal of World Business, 48(3), $285-286$.

Messersmith, J. G., \& Wales, W. J. (2013). Entrepreneurial orientation and performance in young firms: The role of human resource management. International Small Business Journal, 31(2), 115-136.

Mooney, A. (2007). Core competence, distinctive competence, and competitive advantage: What is the difference? Journal of Education for Business, 83(2), 110-115.

Muda, S., \& Rahman, M. R. C. A. (2016). Human capital in SMEs life cycle perspective. Procedia Economics and Finance, 35(October 2015), 683-689.

Narver, J. C., \& Slater, S. F. (1990). The effect of a market orientation on business profitability. Journal of Marketing, 54(4), 20-35.

Nasution, H. N., Mavondo, F. T., Jekanyika, M., \& Oly, N. (2011). Industrial marketing management entrepreneurship : Its relationship with market orientation and learning orientation and as antecedents to innovation and customer value. Industrial Marketing Management, 40(3), 336-345.

O'Cass, A., \& Ngo, L. V. (2011). Examining the firm's value creation process: A managerial perspective of the firm's value offering strategy and performance. British Journal of Management, 22(4), 646-671.

Palacios-marqués, D., Ribeiro-soriano, D., \& Gil-pechuán, I. (2011). The effect of learning-based distinctive competencies on firm performance: A study of Spanish hospitality Firms. Human Resources Management The, 52(2), $102-110$.

Parola, F., Satta, G., Penco, L., \& Profumo, G. (2013). Emerging Port Authority communication strategies: Assessing the determinants of disclosure in the annual report. Research in Transportation Business and Management, 8, $134-147$.

Porter, M. E. (2008). The five competitive forces that shape strategy. Strategy, 86(12), 143.

Prahalad, C. K., \& Hamel, G. (1990). The core competence of the corporation. Handbook on International Political Economy, 249-264.

Ptacek, O., Kaderabkova, B., \& Piecha, M. (2015). Venture capital, private equity and foreign direct investment: Case study of the Czech Republic. Procedia Economics and Finance, 30(15), 680-689.

Risal, M., Sucherly, Kartini, D., \& Hasan, M. (2016). Influence of market orientation and marketing mix strategy on performance of small industrial marketing of processed seaweed products In South Sulawesi province. International Journal of Economics, Commerce and Management, 4(11), 305-318. 
Ritchie, B., \& Brindley, C. (2009). Cultural determinants of competitiveness within SMEs. Journal of Small Business and Enterprise Development, 12(1), 104-119.

Roberts, E. B. (1990). Evolving toward product and market-orientation: The early years of technology-based firms. The Journal of Product Innovation Management, 7(4), 274-287.

Rodriguez-Fernandez, M. (2016). Social responsibility and financial performance: The role of good corporate governance. BRQ Business Research Quarterly, 19(2), 137-151.

Saeed, A., Belghitar, Y., \& Yousaf, A. (2016). Firm-level determinants of gender diversity in the boardrooms : Evidence from some emerging markets. International Business Review, 2015.

Seelos, C., \& Mair, J. (2005). Social entrepreneurship: Creating new business models to serve the poor. Business Horizons, 48(3), 241-246.

Setiadi, A., Doni Purnama, A., Didin, S., Didi, K., \& Ema, O. (2018). Implementation of green IT in education Industries. In 2018 Third International Conference on Informatics and Computing (ICIC), 1-4.

Shabbir, R., Zhang, J., Pitsaphol, C., \& Hassan, W. (2015). The dynamics of value creation in online brand communities : Strategy Map Approach. Information Management and Business Review, 7(1), 48-58.

Shamah, R. A. M. (2012). Innovation within green service supply chains for a value creation. Journal of Modelling in Management, 7(3), 357-374.

Syarifuddin, D., \& Alamsyah, D. P. (2017). Green perceived value for environmentally friendly products: Green awareness improvement. Jurnal Ekonomi Pembangunan, 18(2), 245-255.

Tambunan, T. (2005). Promoting small and medium enterprises with a clustering approach: A policy experience from Indonesia. Journal of Small Business Management, 43(2), 138-154.

Todericiu, R., \& Stăniţ, A. (2015). Intellectual capital - The key for sustainable competitive advantage for the SME's sector. Procedia Economics and Finance, 27(15), 676-681.

Trendafilova, S., Babiak, K., \& Heinze, K. (2013). Corporate social responsibility and environmental sustainability: Why professional sport is greening the playing field. Sport Management Review, 16(3), 298-313.

Tsai, M. T., Chuang, L. M., Chao, S. T., \& Chang, H. P. (2012). The effects assessment of firm environmental strategy and customer environmental conscious on green product development. Environmental Monitoring and Assessment, 184(7), $4435-4447$.

Tunyi, A. A., \& Ntim, C. G. (2016). Location advantages, governance quality, stock market development and firm characteristics as antecedents of African M\&As. Journal of International Management, 22(2), 147-167.

Wheelen, T. L., \& Hunger, J. D. (2012). Strategic Management and Business Policy: Toward Global Sustainability (Pearson (ed.); Thirteenth).

Windsor, D. (2009). Tightening corporate governance. Journal of International Management, 15(3), 306-316.

Ye, F., Zhao, X., Prahinski, C., \& Li, Y. (2013). The impact of institutional pressures, top managers' posture and reverse logistics on performance - Evidence from China. International Journal of Production Economics, 143(1), $132-143$.

Zhou, K. Z., Yim, C. K., \& Tse, D. K. (2005). The effects of Strategic orientations on technology- and market-based breakthrough innovations. Journal of Marketing, 69(2), 42-60.

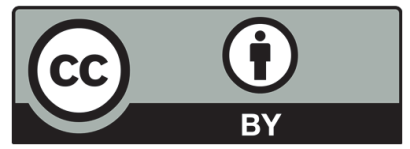

(C) 2020 by the authors; licensee Growing Science, Canada. This is an open access article distributed under the terms and conditions of the Creative Commons Attribution (CC-BY) license (http://creativecommons.org/licenses/by/4.0/). 